\title{
PENGARUH KECERDASAN SPIRITUAL TERHADAP PENINGKATAN KINERJA GURU DI SMA NEGERI 3 TAKALAR KABUPATEN TAKALAR
}

\author{
Baharuddin dan Rahmatia Zakaria \\ Fakultas Tarbiyah dan Keguruan UIN Alauddin Makassar \\ J. HM. Yasin Limpo No. 36 Makassar \\ Email: baharuddinjepot@gmail.com
}

\begin{abstract}
:
This study aims to determine the picture of Teacher Performance in SMA Negeri 3 Takalar of Takalar Regency, and to know the influence of Spiritual Intelligence on Teacher Performance improvement in SMA Negeri 3 Takalar of Takalar Regency. There are two Variables in this research namely Spiritual intelligence $(X)$ and Teacher performance (Y). The population and sample were the teachers of SMA Negeri 3 Takalar of Takalar District namely 79 teachers. The Instrument of the study were the questionnaire guidelines to obtain Spiritual Intelligence and teachers Performance scores. Data analysis techniques were quantitative descriptive analysis techniques using the formula percentage to answer the first problem formulation, and inferential analysis techniques with simple regression to answer the formulation of the second problem. The results showed that: 1). Researchers distributed Likert scale model to know the intelligence and performance of teachers which consisted of 20 items filled by 79 respondents. The data of teachers performance in SMA Negeri 3 Takalar of Takalar Regency showed that teachers who have a low performance of $11.39 \%$ consisted of 9 teachers, and teachers who have high performance $10.12 \%$ consisted of 8 teachers, and teachers who have a moderate performance $78.49 \% 62$ consisted of 26 teachers. 2). The spiritual intelligence resulted in the improvement of teacher performance in SMA Negeri 3 Takalar. This is indicated by the significant test results. obtained by a significance value of 0.000 . Value significance $<0,05(0,000$ $<0,05), \mathrm{HO}$ is rejected. To sum up, it can be concluded that there is significant influence of spiritual intelligence on teacher performance improvement.
\end{abstract}

Keywords: Spiritual intelligence; teacher performance

\section{PENDAHULUAN}

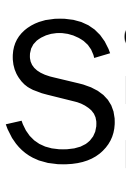
ebagai figur sentral dalam proses pendidikan di sekolah, guru merupakan komponen atau pun unsur yang sangat menentukan keberhasilan suatu pendidikan. Guru memegang peran utama dalam pembangunan pendidikan, khususnya yang diselenggarakan secara formal di sekolah. Guru juga sangat menentukan keberhasilan peserta didik, terutama dalam kaitannya dengan proses pembelajaran.

Guru merupakan komponen yang paling berpengaruh terhadap terciptanya proses dan hasil pendidikan yang berkualitas. Karenanya, upaya perbaikan apapun yang dilakukan untuk meningkatkan kualitas pendidikan tidak akan memberikan sumbangan yang signifikan tanpa didukung oleh guru yang profesional dan 
berkualitas. Salah satu ukuran profesionalisme dan kualitas guru adalah kinerjanya.

Belum maksimalnya kinerja guru dapat dipenguruhi oleh tingkat kesadaran atas tugas pokoknya sebagai seorang guru. Di antara cara menghasilkan kinerja guru yang baik adalah dengan memiliki Kecerdasan Multiple. Kecerdasan tersebut ialah Kecerdasan Intelektual (IQ) ialah kecerdasan yang dibangun oleh otak kiri. Kecerdasan ini mencakup kecerdasan linear, matematik, dan logis sistematis. Kecerdasan ini menghasilkan pola pikir yang berdasarkan logika, tepat, akurat, dan dapat dipercaya. Orang dengan kecerdasan ini akan memiliki analisis yang tajam dan memiliki kemampuan untuk menyusun strategi yang baik. Kecerdasan Emosional (EQ) menjadikan seseorang mampu mengelola emosi dan mengenali perasaan diri sendiri dan orang lain. Termasuk di antaranya kemampuan mengelola emosi pribadi, dan kemampuan berinteraksi sosial. Orang yang memiliki kecerdasan emosional yang baik mampu secara tepat mengelola ekspresi wajah seperti tersenyum, cemberut, gembira dan sedih, serta mampu mengatur volume dan intonasi suara sesuai kebutuhan dan kondisi lingkungan. Kecerdasan Spritual (SQ) merupakan kemampuan mengerti dan memberikan makna spiritual atas kehidupan.

Seiring dengan hasil pengamatan selama observasi yang dilakukan oleh penulis di SMA Negeri 3 Takalar, ditemukan masih adanya keluhan dari masyarakat tentang keadaan guru. Guru mempunyai indikasi yang cenderung memiliki semangat mengajar menurun, kurang disiplin, mengjar tidak tepat waktu, sehingga berdampak pada output alumni, pemicunya meliputi: sikap dan komitmen kerja/mengajar rendah, guru kurang memahami tugas dan tanggung jawab yang dibebankan kepadanya, guru kurang memiliki inisiatif ketika mengajar. Hal inilah yang kemudian mempengaruhi kualitas kinerja seorang guru.

Berdasarkan uraian di atas, maka penulis tertarik untuk melakukan penelitian dengan judul "Pengaruh Kecerdasan Spritual Terhadap Peningkatan Kinerja Guru di SMA Negeri 3 Takalar".

Berdasarkan latar belakang yang telah dikemukakan di atas, maka masalah pokok yang dikaji dalam penelitian ini, dapat dirumuskan sebagai berikut:

1. Bagaimana gambaran Kinerja guru di SMA Negeri 3 Takalar?

2. Adakah pengaruh antara kecerdasan spritual dengan Kinerja guru di SMA Negeri 3 Takalar?

\section{TINJAUAN PUSTAKA}

\section{Kecerdasan Spritual}


Kecerdasan spiritual dalam kamus Bahasa Indonesia, spiritual adalah hal-hal yang menyangkut nilai-nilai kemanusiaan yang bersifat non-materi terdapat dalam bingkaian dan terselubung dalam jiwa dan hati manusia seperti: kebaikan, kebenaran, keindahan, kesucian cinta, rohani dan kejiwaan (Burhani, Hasbi, Lawrens, tt:627). Dalam agama sifat-sifat seperti ini yang menyangkut sisi kemanusiaan yang bersifat non-materi, seperti konsistensi (istiqamah), kerendahan hati (tawadlu), berusaha dan berserah diri (tawakal), ketulusan(keikhlasan), totalitas (kaffah), keseimbangan (tawazun), dan integritas \& penyempurnaan (ihsan), semua itu dinamakan Akhlakul Karimah. Dalam kecerdasan spiritual, hal-hal inilah yang dijadikan tolak ukur kecerdasan spiritual (Agustian, 2001: 199).

Edward Lee Thorndike dalam Saifuddin Azwar mengatakan bahwa intelegensi (kecerdasan) adalah kemampuan dalam memberikan respon yang baik dari pandangan kebenaran atau fakta (Azwar, 2007: 6). Sinetar dalam masaong dan tilomi menafsirkan kecerdasan spiritual sebagai pemikiran yang terilhami. Selanjutnya dikatakan kecerdasan spiritual adalah cahaya, ciuman kehidupan yang membangunkan keindahan tidur, membangunkan orang-orang dari segala usia dan segala situasi.

Iskandar berpendapat bahwa kecerdasan spiritual merupakan kemampuan individu terhadap mengelola nilai-nilai, norma-norma dan kualitas kehidupan dengan memanfaatkan kekuatan pikiran bawah sadar atau suara hati (GOD SPOT) (Iskandar, 2012: 65). Dalam hal ini, seseorang yang memiliki kecerdasan spiritual yang tinggi, dia mampu mengelola nilai, norma dan memanfaatkan kekuatan pikiran bawah sadarnya.

Selain IQ dan EQ kita juga harus memiliki SQ atau yang biasa juga disebut kecerdasan spiritual. Kecerdasan spiritual adalah kecerdasan untuk menghadapi dan memecahkan persoalan makna atau nilai, yaitu kecerdasan untuk menempatkan perilaku dan hidup kita dalam konteks makna yang lebih luas dan kaya, kecerdasan untuk menilai bahwa tindakan atau jalan hidup seseorang lebih bermakna dibandingkan yang lain (Marshal, 2000: 3).

Kecerdasan spiritual adalah kecerdasan jiwa yang dapat membantu seseorang membangun dirinya secara utuh. Kecerdasan spiritual tidak tidak bergantung pada budaya atau nilai. Tidak mengikuti nilai-nilai yang ada, tetapi mengciptakan kemungkinan untuk memiliki nilai-nilai sendiri (Sunar P, 2010: 248249).

Kecerdasan spiritual muncul karena adanya perdebatan antara IQ dan EQ, oleh karena itu istilah tersebut muncul sebab IQ dan EQ dipandang hanya menyumbangkan sebagian dari penentu kesuksesan seseorang dalam hidup. Ada faktor lain yang ikut berperan yaitu kecerdasan spiritual yang lebih menekankan JURNAL IDAARAH, VOL. 2, NO. 1, JUNI 2018 
pada makna hidup dan bukan hanya terbatas pada penekanan agama saja (Hoffman, 2002: 131).

Sedangkan di dalam ESQ, kecerdasan spiritual adalah kemampuan untuk memberi makna ibadah terhadap setiap perilaku dan kegiatan, melalui langkahlangkah dan pemikiran yang bersifat fitrah, menuju manusia yang seutuhnya (hanif), dan memiliki pola pemikiran tauhidi (integralistik), serta berperinsip "hanya karena Allah" (Agustian, 2001: 57).

Kecerdasan spiritual (SQ) dapat memfasilitasi dialog antara pikiran dan emosi, antara jiwa dan tubuh. Dia juga mengatakan bahwa kecerdasan spiritual juga dapat membantu seseorang untuk dapat melakukan transedensi diri (Berman M, 2001: 98).

Kecerdasan spiritual adalah kecerdasan jiwa yang dapat membantu seseorang membangun dirinya secara utuh.Kecerdasan spiritual tidak tidak bergantung pada budaya atau nilai.Tidak mengikuti nilai-nilai yang ada, tetapi mengciptakan kemungkinan untuk memiliki nilai-nilai sendiri (Sunar P, 2010: h.248-249).

Zohar dan marshal dalam Masaong dan Tilomi memperkenalkan istilah kecerdasan spiritual (SQ) setelah berpuluh-puluh tahun penelitiannya. Menurut Zohar dan Marshal dalam Masaong dan Tilomi bahwa kecerdasan spiritual sebagai puncak kecerdasan. Kecerdasan spiritual tidak identic dengan formal, karena itu kecerdasan ini tidak memiliki satu agama (Masaong \& Tilomi, tt: 95). Bahkan seorang atheis pun dapat memiliki kecerdasan spiritual yang tinggi. Kecerdasan tersebut merupakan kemampuan pemikiran yang tinggi, yang memungkinkan petunjuk moral yang kuat, sehingga berakibat timbulnya kemampuan membedakan antara yang salah (tidak bermakna) dengan yang benar atau bermakna.

Dari beberapa pengertian di atas dapat disimpulkan bahwa kecerdasn spiritual adalah suatu wawasan pemikiran yang luar biasa mengagumkan yang mendapat inspirasi, dorongan, dan efektivitas yang terinspirasi penghayatan ketuhanan sehingga dapat mengenali dan meyakini tuhannya. Untuk melihat tingkat kecerdasan seseorang dapat diamati dari cara dan kemampuannya dalam melakukan suatu tindakan.

\section{Kinerja}

Manajemen kinerja adalah suatu cara untuk mendapatkan hasil yang lebih baik bagi organisasi, kelompok dan individu dengan memahami dan mengelola kinerja sesuai dengan target yang telah direncanakan, standar dan persyaratan kompetensi yang telah ditentukan. Dengan demikian manajemen kinerja adalah sebuah proses untuk mendapatkan apa yang harus dicapai, dan pendekatannya untuk mengelola dan pengembangan manusia melalui suatu cara yang dapat 
meningkatkan kemungkinan bahwa sasaran akan dapat dicapai dalam suatu jangka waktu tertentu baik pendek maupun panjang (Dharma, 2005: 25).

Kinerja adalah aktivitas yang berkaitan dengan unsur-unsur yang terlibat dalam suatu proses untuk menghasilkan suatu output. Lebih lanjut kinerja adalah hasil dari fungsi suatu pekerjaan atau kegiatan tertentu selama suatu periode waktu tertentu. Kinerja dapat dilihat dari berbagai sudut pandang, tergantung pada tujuan masing-masing organisasi (Siagian, 2002: 17).

Kinerja SDM adalah prestasi kerja atau hasil kerja baik kuantitas, kualitas, kesalahan, dan kecermatan yang dicapai SDM persatuan periode waktu dalam melaksanakan tugas kerjanya sesuai dengan tanggung jawab yang telah diberikan kepadanya (Syafri, 2005: 9). Untuk itu kinerja dapat dicapai oleh seseornag atau kelompok dalam suau organisasi, sesuai dengan wewenang dan tanggung jawab masing-masing, dalam rangka upaya pencapaian tujuan organisasi bersangkutan secara legal, tidak melanggar hukum serta sesuai moral maupun etika.

Standar kinerja perlu dirumuskan untuk dijadikan acuan dalam mengadakan perbandingan terhadap apa yang dicapai dan apa yang diharapkan, atau kualitas kinerja adalah wujud perilaku atau kegiatan yang dilaksanakan dan sesuai dengan harapan dan kebutuhan atau tujuan yang hendak dicapai secara efektif dan efisien. Kualitas kinerja guru dinyatakan dalam Peraturan Mentri Pendidikan Nasional Republik Indonesia nomor 16 tahun 2007 tentang standar kualifikasi akademik dan Kompetensi guru. Dijelaskan bahwa standar kompetensi guru dikembangkan secara utuh dari empat kompetensi utama, yaitu kompetensi pedagogik, kepribadian, sosial, dan professional. Keempat kompetensi tersebut terintegrasi dalam kinerja guru (Rusman, 2013: 50-53).

Pengertian kinerja atau performance merupakan gambaran mengenai tingkat pencapaian pelaksanaan suatu program kegiatan atau kebijakan dalam mewujudkan sasaran, tujuan, visi, dan misi organisasi yang dituangkan melalui perencanaan strategis suatu organisasi. Kinerja dapat diketahui dan diukur jika individu atau sekelompok karyawan telah mempunyai kriteria atau standar keberhasilan tolak ukur yang ditetapkan oleh organisasi. Oleh karena itu, jika tanpa tujuan dan target yang ditetapkan dalam pengukuran, maka kinerja pada seseorang atau kinerja organisasi tidak mungkin dapat diketahui bila tidak ada tolak ukur keberhasilannya (Moeheriono, 2012: 95).

Manajemen kinerja adalah proses yang sistematik, artinya untuk memperbaiki kinerja diperlukan langkah-langkah atau tahap-tahap yang terencana dengan baik. Proses perbaikan kinerja bukan merupakan kerja jangka pendek, melainkan merupakan proses evolutif yang berjangka panjang. Manajemen berbasis kinerja tersebut pada akhirnya akan berdampak pada perbaikan budaya kinerja. Budaya merupakan produk suatu tradisi yang panjang. Perubahan budaya JURNAL IDAARAH, VOL. 2, NO. 1, JUNI 2018 
memerlukan waktu yang lama. Demikian juga melakukan perubahan budaya kinerja memerlukan perencanaan yang matang, holistik, dan jangka panjang (Mahmudi, 2013: 5).

Berdasarkan pendapat para ahli di atas, dapat disimpulkan bahwa kinerja guru adalah hasil kerja yang dapat dicapai oleh seorang guru dilembaga pendidikan atau madrasah sesuai dengan tugas dan tanggung jawabnya dalam mencapai tujuan pendidikan. Dengan kata lain, hasil kerja yang dicapai seseorang dalam melaksanakan tugas-tugas yang dibebankan kepadanya didasarkan hasil kecakapan, pengalaman, dan kesungguhannya.

\section{METODOLOGI PENELITIAN}

Penelitian ini merupakan penelitian lapangan (fieldreserch) yang mengharuskan peneliti terjun langsung kelapangan dengan menggunakan metode penelitian kuantitatif. dengan pendekatan kuantitatif. Lokasi penelitian dilakukan di SMA Negeri 3 Takalar yang terletak di Kelurahan Kalabbirang, Kecamatan Patalassang Kabupaten Takalar, Provinsi Sulawesi Selatan.

Populasi untuk penelitian ini adalah semua guru di SMA Negeri 3 Takalar yang berjumlah 79 orang. Sampel yang diambil dalam penelitian ini adalah sampel jenuh yaitu dari seluruh jumlah guru yang berada di SMA Negeri 3 Takalar sebanyak 79 orang.

Teknik pengumpulan data untuk penelitian ini akan dilakukan dengan beberapa cara yaitu wawancara, kuesioner dan dokumentasi. Teknik analisis yang digunakan dalam penelitian ini adalah; analisis statistik deskriptif dan statistik inferensial.

\section{HASIL PENELITIAN DAN PEMBAHASAN}

\section{Gambaran Kinerja guru di SMA Negeri 3 Takalar Kab. Takalar}

Berdasarkan hasil penelitian yang telah dilakukan terhadap guru SMA Negeri 3 Takalar Kabupaten Takalar. Bisa dilihat bahwa kinerja guru-guru tersebut sesuai dengan peraturan yang telah pemerintah keluarkan, dan kebanyakan guru di sekolah ini telah tersertifikasi. Penulis mengumpulkan data melalui hasil kuesioner yang di kerjakan oleh guru-guru tersebut, yang kemudian di berikan skor pada masing-masing pernyataan.

Berdasarkan hasil penelitian, diperoleh hasil statistik deskriptif dari 79 responden memiliki skor kuisioner kinerja guru minimum 29, skor maksimum 50 , sehingga rangenya 21 , dalam praktik semakin besar range semakin bervariasi suatu data. Jumlah skor 5523, rata-rata 92,5, standar deviasi atau simpangan 
baku sebesar 12,839 dan varians 164.828, standar deviasi dan varians menunjukan tingkat keberagaman data.

Hasil kategori juga menunjukkan bahwa guru yang memiliki kinerja rendah $11,39 \%$ dengan jumlah frekuensi 9 guru, dan guru yang memiliki kinerja tinggi $10,12 \%$ dengan jumlah frekuensi 8 guru, dan guru yang memliki kinerja sedang $78,49 \%$ frekuensi 62 guru.

\section{Pengaruh Kecerdasan Spritual terhadap Peningkatan Kinerja Guru}

Setelah dilakukan uji normalitas yang menunjukkan data berdistribusi normal. Kemudian dilakukan uji linearitas yang menunjukkan bahwa antara kecerdasaan spritual dengan kinerja guru memiliki hubungan yang linear atau berpola linear. Pengaruh Kecerdasan Spiritual terhadap peningkatan Kinerja guru di SMA Negeri 3 Takalar dapat diketahui dengan melakukan uji regresi linear sederhana. Berdasarkan hasil uji regresi yang dilakukan, konstanta dan koefisien persamaan diperoleh dari kolom $B$, sehingga persamaan regresi : $Y=22,633+0,440 \mathrm{X}$. Dari analisis diperoleh $\mathrm{t}$ hit $=4,631 \mathrm{dan} \mathrm{p}$ - value $=0,000<0,05$ atau $\mathrm{H}_{0}$ ditolak. Dengan demikian, kecerdasan spritual berpengaruh terhadap kinerja guru di SMA Negeri 3 Takalar Kab. Takalar.

Koefisien regresi sebesar 0,440 mengindikasikan bahwa besaran penambahan tingkat kinerja guru setiap penambahan jawaban untuk variabel kecerdasan spritual. Berdasarkkan hasil analisis diperoleh nilai Rxy sebesar 0,467. Hal ini menunjukan bahwa persentase sumbangan kecerdasan spiritual terhadap peningkatan kinerja guru sebesar 46,7 \%, sedangkan sisanya 53,3\% dipengaruhi olehh variabel lain yang tidak dimasukan ke dalam penelitian ini.

Pengujian Linearitas dan Signifikasi Persamaan Regresi ditentukan berdasarkan ANOVA Table dan ANOVAa, hasilnya menunjukkan uji linearitas persamaan garis regresi diperoleh dari baris deviation from linearity, yaitu $F_{\text {hit }}$ $=1.867$, dengan $p$ - value $=0,060>0,05$. Hal ini berarti Ho diterima atau persamaan regresi $Y$ atas $X$ adalah linear atau berupa garis linear.

Pengujian hipotesis pada penelitian ini digunakan pengujian secara parsial. Kriteria penentuan pengujian dilakuan dengan dua cara yaitu uji $t$ dan signifikansinya.

Uji t digunakan untuk mengetahui apakah secara parsial kecerdasan spritual (SQ) berpengaruh secara signifikan terhadap kinerja guru. Pengujian menggunakan tingkat signifikansi 0,05 dan 2 sisi. Kesimpulan dari uji t menunjukkan nilai signifikansi $<0,05(0,000<0,05)$ atau $t_{\text {hit }}(4,631)>t_{\text {tabel }}(1,665)$, maka $\mathrm{H}_{0}$ ditolak. Jadi dapat disimpulkan bahwa terdapat pengaruh yang signifikan antara kecerdasan spritual terhadap peningkatan kinerja guru 
Berdasarkan uraian di atas dapat disimpulkan bahwa kecerdasan spiritual dapat mempengaruhi kinerja guru, hal ini berarti semakin baik kecerdasan spiritual maka akan semakin baik pula kinerja guru. Guru yang kecerdasan spiritualnya tinggi dan didukung lingkungan kerja yang juga spiritual, secara positif menjadi lebih kreatif, memiliki kepuasan kerja yang tinggi, mampu bekerja dengan baik secara tim, dan memiliki komitmen yang tinggi terhadap organisasi, Kecerdasan spiritual memberikan manusia moral, kemampuan menyesuaikan diri berdasarkan pengalaman dan cinta serta kemampuan setara.

\section{KESIMPULAN DAN SARAN}

Berdasarkan hasil penelitian dan pembahasan, maka dapat ditarik kesimpulan sebagai berikut:

1. Berdasarkan hasil penelitian ini, peneliti melakukan penyebaran skala yaitu model skala likert untuk mengetahui kecerdasandan kinerja guru yang terdiri dari 20 item pernyataan yang diisi oleh 79 responden. analisis data kinerja guru di SMA Negeri 3 Takalar Kab. Takalar, menunjukkan diketahui bahwa guru yang yang memiliki kinerja redah 11,39 \% dengan jumlah frekuensi 9 guru, dan guru yang memiliki kinerja tinggi 10,12 \% dengan jumlah frekuensi 8 guru, dan guru yang memliki kinerja sedang 78,49\% frekuensi 62 guru.

2. Kecerdasan spiritual yang dimiliki oleh guru mengakibatkan terjadinya peningkatan kinerja guru di SMA Negeri 3 Takalar. Hal ini di tunjukkan oleh hasil uji sigifikan yang diperoleh nilai signifikansi sebesar 0,000. Nilai signifikansi $<0,05(0,000<0,05)$, maka $\mathrm{H}_{0}$ ditolak. Jadi dapat disimpulkan bahwa terdapat pengaruh yang signifikan kecerdasan spiritual terhadap penngkatan kinerja guru.

Berdasarkan hasil penelitian yang disimpulkan oleh peneliti maka peneliti memiliki beberapa saran untuk dapat digunakan di SMA Negeri 3 Takalar Kabupaten Takalar terkait dengan Pengaruh Kecerdasan Spritual Terhadap Peningkatan Kinerja Guru di SMA Negeri 5 Takalar Kabupaten Takalar sebagai berikut:

1. Melihat kecerdasan spritual berpengaruh terhadap peningkatan kinerja guru di SMA Negeri 3 Takalar Kabupaten Takalar, hendaknya pihak pimpinan kepala Sekolah berusaha memperhatikan kinerja guru dan mengembangkan kecerdasan yang dimiliki oleh guru utamanya kecerdasan spritual, kecerdasan itelektual, dan kecerdasan emosional, karena semakin baik kecerdasan yang dimiliki guru, maka akan semakin baik pula kinerjanya.

2. Kepala sekolah hendaknya senantiasa mengingatkan pentingnya memahami Kecerdasan Spiritual dalam melakukan aktifitas di sekolah. 
3. Bagi peneliti selanjutnya, peneliti menyarankan untuk melanjutkan penelitian yang serupa dengan melihat faktor-faktor yang lain yang mempengaruhi kinerja guru dan lain sebagainya.

\section{DAFTAR PUSTAKA}

Agustian, Ary Ginanjar. ESQ Emotional Spritual Quotient, Jakarta: Arga, 2001.

Arfan Tilomoni, Abd. Kadim Masaong. Kepemimpinan Berbasis Multipate Intelegence,

Arikunto, Suharsimi. Prosedur Penelitian Suatu Pendekatan Praktek, Jakarta: Rineka Cipta, 2002.

Asf. Jasmani dan syaiful mustafa. Supervisi Pendidikan Terobosan Baru Dalam meningkatkan kinerja pengawas sekolah dan guru,

Aswar,Saifuddin. Pengantar Psikologi Intelegensi, Jakarta: Gramedia

Azwar Saiful, Dasar- Dasar Psikometri, Yogyakarta: Pustaka Pelajar, 2007

Berman M. Devoloping SQ spiritual intellegence throught ELT, http://www.eltnesletter.12 juni 2001.

Burhani Ms -Hasbi Laurens. Kamus ilmiah populer, Jombang: Lintas Media

Dharma, Surya.Manajemen Kinerja Falsafah Teori Dan Penerapannya,Yogyakarta: Pustaka Pelajar, 2005.

Getteng, Abd Rahman. Menuju Guru Profesional Dan Ber-Etika. Yogyakarta: Grha Guru, 2009.

Rucky, Sistem Manajemen Kinerja, Jakarta: Gramedia Media Pustaka, 2002

Hadjar Ibnu, Dasar-dasar Metodologi Penelitian Kuantitatif dalam Pendidikan, Jakarta: Raja Grafindo Persada, 1999

Hasan Iqbal, Pokok-pokok Materi Statistik 2 Statistik Infrensial, Jakarta: Bumi Aksara, 2010

Haziq Abdullah, Meta Kecerdasan dan Kesadaran Multikultural

Hoffman. Psychological Testing At Work, New York: Mc Graw Hill, 2002

Iskandar, Psikologi Pendidikan, sebuah orientasi baru, Jakarta: Referensi, 2012

Mahmudi. Manajemen Kerja Sektor Publik, Yogyakarta: Unit Penerbit Dan Percetakan Sekolah Tinggi Ilmu Manajemen, 2013.

Moeheriono. Pengukuran Kinerja Berbasis Kompetensi, Jakarta: Rajagrafindo Persada, 2012. 
Nasehudin, Toto Syatori dan Nanang Gozali. Metode Penelitian Kuantitatif, Bandung: Pustaka Setia,2012.

P, Dwi Sunar. Edisi Lengkap Tes IQ, EQ, Dan SQ ( Cara Mudah Mengenali Dan Memaknai Kepribadian), Jogjakarta: Flash Books, 2010.

Ridwan,dkk. Pengantar Statistik untuk Penelitian Pendidikan, Sosial, Komunikasi dan Bisnis, Jakarta: Alfabeta, 2009.

Riduwan, Belajar Mudah Penelitian untuk Guru-Karyawan dan Peneliti Pemula, Bandung: Alfabeta, 2008

Rivai, Veitzhal. Performance Apparaisal Sistem Yang Tepat Untuk Menilai Kinerja Karyawan Dan Meningkatkan Daya Saing Perusahaan, Jakarta: Rajagrafindo Persada, 2011.

Rusman. Model-Model Pembelejaran Mengembangkan Profesionalisme Guru, Jakarta: Rajagrafindo Persada, 2013.

Siagian. Manajemen Sumber Daya Manusia, Jakarta: Bumi Aksara.2002.

Simamora Henry. Manajemen SDM, Yogyakarta: STIE YKPN, 2000

Sugiyono. Statistika Untuk Penelitian, Bandung: Alfabeta, 2015.

Syafri, Mangkunegara. Manajemen Sumber Daya Manusia Stratejik, Jakarta: Ghalia, 2005.

Syaiful Mustafa, Jasmani Asf, Supervisi Pendidikan Terobosan Baru dalam Meningkatkan Kinerja Pengawas Sekolah dan Guru

Tiro Muhammad Arif, Dasar-Dasar Statistika, Makassar: Badan Penerbit UNM, 2000

Umiarso, Abd. Wahab. Kepemimpinan Pendidikan dan Kecerdasan Spritual,

Wiyono, Ki Slamet. Berfikir dengan IQ,EQ,Dan SQ, Semarang: Sindur Press, 2008.

Wibowo, Manajemen Kinerja - edisi kelima, Jakarta: Rajawali Pers, 2016

Yani Fitri. Pengaruh Kecerdasan Intelektual, Kecerdasan Emosional, Kecerdasan Spritual Terhadap Pemahaman Akuntansi, Jurnal, Pekanbaru: Fakultas Keguruan dan IImu Pendidikan

Zohar, D Marshal I.Spiritual Intelligence The Ultimate Intelligence, Great Britain: Bloomsbury, 2000.

Zuriah Nurul. Metodologi Penelitian Sosial dan pendidikan, Jakarta: Bumi Aksara.2007. 